\title{
Factorial Validity of an Instrument in Order to Measure the Organizational Climate in Preschoolers
}

\author{
Dolores G. Álvarez ${ }^{1}$, Veronica E. Ruiz ${ }^{1}$, Joseph F. Ojeda ${ }^{2} \&$ Nidia I. Ramírez ${ }^{1}$ \\ ${ }^{1}$ Polytechnic University of Guanajuato, Cortazar, Guanajuato, Mexico \\ ${ }^{2}$ Polytechnic University of Aguascalientes, Aguascalientes, Mexico \\ Correspondence: Dolores G. Alvarez, 1001 South University Avenue, Cortazar, Guanajuato, 38483, Mexico. Tel: \\ 011-5246-1441-4308. E-mail: dalvarez@upgto.edu.mx
}

Received: November 18, 2016

Accepted: November 28, $2016 \quad$ Online Published: December 28, 2016

doi:10.5539/ijbm.v12n1p111

URL: http://dx.doi.org/10.5539/ijbm.v12n1p111

\begin{abstract}
The objective of this research was to propose an instrument based on the ECL Valenzuela (ECL, acronym for Work Climate Scale in Spanish), which could maintain an optimal level of reliability, but with its slim structure. The methodology used was a quantitative approach with no experimental transactional design which used Exploratory Factor Analysis AFE (for its acronym in Spanish), as a consequence 37 items were able to be reduced and the structure was adapted to attend preschools, maintaining the level of reliability of the instrument, as a result a new instrument CL Preschool took place. It is concluded that from the dimensions: Collaborative Environment, Manager Relationships, Professional Development, Compensation, Membership, Information, Training, Organization and Labor Media, the organizational climate can be explained from the preschooler research subjects.
\end{abstract}

Keywords: measurement of organizational climate, preschoolers, human capital management

\section{Introduction}

This research aims to contribute to the field of human capital management organizations in the education sector adapting the assessment tool of organizational climate ECL from Valenzuela, based on the results obtained in preschool institutions.

In education, understanding and comprehending the labor context in which teachers and non-teaching work, makes studies in this workplace have a substantial importance in understanding the work in educational organizations (Ojeda, 2013). The term "capitalization of education" was transformed in Mexico to "corporatization of education" and it is a concept that has been taking root since 1990 (Montaño, 2001), although there exist several studies regarding this topic in university (Ibarra, 1998) empirical approaches in other levels of education are significantly limited or reduced (Ojeda, 2014) and at preschool education in Mexico and in general at a global level, the evidences are scarce.

\section{Study material and area descriptions}

\subsection{The Organizational Climate}

The theory of organizational climate goes back to the ideas of Tolman (1932) of cognitive maps defined as the individual scheme that people build, to give them sense of their own environment (Silva,1992). Focused on organizational aspects Lewin, Lippitt and White (1939) relate human behavior and the environment through the concept of "psychological atmosphere" (Bustamente, Hernandez and Yañez, 2009). However the vast majority of researchers, in the area of the organizations, agree on placing the beginning of this trend to the investigations on which Elton Mayo and his colleagues joined - in 1927 - at the Hawthorne plant of the company Western Electric in Illinois, USA, who began with a series of systematic researches to determine the impact of perceptions on job performance (Hernandez, 2008).

The need to know the functioning of organizations, implies the description of the environment in which the activities of the individuals is developed (Rodriguez, 1996). This work environment can be described through the organizational climate (Garcia, 2006) and the organizational climate is one of the factors that actively influence work performance (Fuentes, 2004). 
The first evidence on climate studies traces back to Lewin (1936), who used the term "living space" as a mean to explain the motivational and emotional reactions of individuals adapting to the change (Hernandez, 2008).

Lewin, Lippitt and White (1939), mentioned by Diaz and Zavala (2006) and by Hernandez (2008) examined the climate as an "empirical reality", in order to study the behavioral effects in three different atmospheres, induced by leadership (autocratic, democratic and laissez-faire); They also used the terms "social climate" and "social atmosphere" as synonyms to designate the psychological conditions created by the leaders in the groups (Hernandez, 2008).

The climate is an essential intervening variable between the person and the environment. In the 1960s, this intervening relationship evolved into a subjective reality. Hence the realities of the organization are only understood by the perception of its members, thus allowing the climate to be seen as a filter through which the target phenomena must pass. The term organizational climate emerged in the 1960s. In 1967, Litwin and Stringer simulated three companies, in which they created different internal environments, designed to meet the need of power, the need of achievement and the need of affiliation (Ojeda, 2013).

\subsection{Measuring Organizational Climate}

The organizational climate has been defined and conceptualized by different authors, in an analysis of concepts ranging from 1950 to 2010 organizational climate was found to be understood as a perception $(60 \%)$ and a behavior (21\%), as a description of an environment (13\%) and organizational structures (4\%) and as a multidimensional construct (3\%) of a total of 149 definitions (Ojeda, 2013).

Since 1936, the concept and studies of the organizational climate began to establish (Hernandez, 2008); and have been related with other constructs, such as satisfaction, (Peiro, González and Ramos, 1991; Dorman, 1999; Chiang, 2004; culture (Hernandez, 2008), communication (O'Driscoll and Evans, 1988); the structure, (Schneider, 1975), size (Muñoz, 1998) standardization - formalization, is another construct with which the organizational climate has been linked or related to (Litwin and Stringer, 1968) technology - update (McKnigth and Webster, 2001), organizational processes, (Goncalves, 2004), leadership (Zuluaga, 2001). innovation and performance have been reviewed by Michela and Burke (2000).

More recently the implication of the performance factor has been reviewed regarding the organizational climate (Toro and Cabrera, 2002), Social interaction has also been linked with it, (Bustos, Miranda and Peralta, 2004), complementarily, bonds have been found among the employee's participation as an indicator of organizational climate, (Caracheo, 2001).

The pride of belonging to the organization has been linked as a generator of organizational climate and at the same time, it has been described as a factor of organizational climate (Gunter and Furnham, 1996).

Organizational commitment, has been tested as a predictor of organizational climate (Hernández-Molinar, 2009). Some authors have suggested that customer satisfaction is a result of a suitable organizational climate (Bernhardt et al., 2000) and the quality of service, (Schneider et al. 2000).

Likewise the rate of accidents has tried to be linked as a desirable product of a positive organizational climate (Salminen \& Seppala, 2005).

Finally, the dimensions of training, (Rouiller and Goldstein, 1993), sexual harassment (Fitzgerald et al., 1997), feeling good, (Meyer, Allen and Smith, 1993), and motivation (Velázquez, 2004) have been studied as factors that create a positive organizational climate within the organization.

The Cliouning instrument was developed by Mejia Reyes and Arzola (2006) from the assumptions of Litwin and Stringer (1968) and Stringer (2002) to measure the organizational climate in higher education institutions, as a basis for the implementation of a quality management system, the model was designed to manage the work environment through an interdisciplinary environment, including the human sciences, engineering, statistical and quality management. It was designed parting from three dimensions, institutional management, personal challenges and interaction, these dimensions showed consistency in terms of reliability and validity, other studies have shown the consistency and validity of the instrument in other contexts (Reyes, 2007; Brito and Jimenez, 2009). For Hidalgo, Xicoténcatl and Rodriguez (2008) the great strength of cliouning lies on the fact that it places the person in its most holistic dimension, in the center of the organization and the organization serves as evolutionary entity that embraces the person and it interacts with him or her.

The Scale Work Climate (ECL for its acronyms in Spanish) is an instrument designed by Valenzuela (2005) that measures organizational climate in educational institutions according to the dimensions of personal work, supervision, teamwork and relationships with peers, management, communication, physical and cultural 
environment, training and development, promotion and career, salaries and benefits and pride of ownership. This instrument has been tested by Salaiza and Vera (2007) in a normal school, Garza (2010) tested it in a governmental organism, their results confirm the validity and reliability of size and scale. Ojeda (2014) reports a reliability of 0.965 in 17 institutions of primary education in an area or zone of the state of Guanajuato, Mexico, and stratifies dimensions in three levels, at the highest level dimensions of pride, monitoring, communication, promotion and administration were placed, at the intermediate level the dimensions of development, training and teamwork were placed, and at the last level the dimension of personal work remained. He identified the dimension of administration (also known as management) as the central axis linking the dimensions of group type (teamwork, monitoring and communication) with the dimensions of a personal type (personal work, training, development, promotion and physical environment) and only the dimension of pride remained disconnected in this study. Other researchers have demonstrated the validity and reliability of ECL (Valenzuela, 2005, Salaiza, 2008, Garza, 2010, Prisco and Salaiza, 2012, Sotelo, Arrieta and Figueroa, 2015 and Garcia and Mendoza, 2015)

\subsection{The Organizational Climate in Preschool}

There are actually very few studies published in reference to the study of organizational climate phenomenon in preschool institutions, among which were possible to identify are those of Gúzman, Bojorquez and Serrano (2009), who measured the organizational climate according to the dimensions of identification and interaction, leadership, communication, collaboration, training and working conditions, the result evidenced a lack of attention in the areas of recognition, training and salary.

Hinojosa (2010) analyzed the organizational climate through the dimensions of environment and working climate of the organization, commitment and alignment with the institution, degree of satisfaction among the employee's and the institution and relationship and interaction among peers.

Goñi (2011) analyzed the organizational climate in preschool employee's through the dimensions of structure, identity, management style, availability of resources, motivation, stability, teamwork, communication, responsibility and interpersonal relations. In general, the most important dimension for the teachers was the motivation, for the assistants was the identity linked to the recognition of the workplace as a pleasant space to be, and for non-teaching personal, the dimension that was the most significant was the availability of resources which involves an prevention exercise to achieve its obligations and tasks.

Martinez and Rodriguez (2011) measured the organizational climate in preschool educational institutions through the dimensions of resources and general environment, relationships with directors and non-teaching staff, coworkers, their position held and the enjoyment of working with children.

Paredes, Sanchez and De la Cruz (2012) correlated the organizational climate with teaching performance in a preschool area or zone, the study sample consisted of 60 teachers and 12 directors. The perceptions of a positive organizational climate are related to job satisfaction, work commitment and personal development. In addition, it can influence the performance of work-related behaviors and in the case of teachers, their work is performed within of the classroom and directly impacts preschool students (Boyce, 2010; Goñi, 2011 and Paredes, Sánchez and Salaiza, 2012).

With so little evidence regarding the organizational climate of the phenomenon behavior in preschool institutions, it is considered highly important to collaborate with new and perspective contemporary studies to address this practical life construct.

\section{Methods}

This research demonstrates a quantitative research of a non-experimental transactional design of correlational scope, afterwards, the technique of Analysis of Exploratory Factor (AFE) was used, which purpose was:

To propose a statistically validated instrument for preschoolers from ECL Valenzuela.

Therefore Hi: The level of Work climate scale in preschool in "Laja Bajío" is determined by the dimensions of Preschool instrument CL: Collaborative environment, relationship with directors or boss, professional development, compensation, sense of belonging, information, training, organization and working means or material.

This instrument was applied in the year 2015 in public preschool institutions, a population of 688 with a stratified sample of 564 employees, generating a reliability index of $95 \%$ and a margin of error of $2.5 \%$ (see Table 1). 
Table 1. Sample

\begin{tabular}{lllllll}
\hline Sector & City & Zone No. & Total personal per zone & Percentage regarding population & Stratified sample & Real sample \\
\hline \multirow{4}{*}{13} & A. sector & 13 & 2 & 0.31 & 1.5 & 2 \\
& Cortazar & 23 & 72 & 11.30 & 53.8 & 62 \\
& Cortazar & 73 & 88 & 13.81 & 65.8 & 74 \\
& Villagrán & 79 & 101 & 15.86 & 75.5 & 84 \\
& Celaya & 7 & 113 & 17.74 & 84.4 & 86 \\
& Celaya & 38 & 106 & 16.64 & 79.2 & 92 \\
& Celaya & 64 & 98 & 15.38 & 73.2 & 82 \\
& Celaya & 90 & 106 & 16.64 & 79.2 & 80 \\
\hline
\end{tabular}

The study subjects were employees of two sectors which included the municipalities of Cortazar, Celaya and Villagran, all these in the state of Guanajuato.

The document was applied to two instruments in the same session and data analysis was performed with SPSS version 19 software.

The analysis of the results for the generation of the instrument was based on factor analysis.

The ECL Valenzuela instrument has a type design Likert scale, with 5 levels of responses ranging from a value from 1 to 5 and shows positions of support or rejection of the written items.

The 80 items of ECL Valenzuela integrate the 10 dimensions: Personal work; supervision; teamwork and relationships with coworkers; administration; communication; physical and work environment, training and development; promotion and career; salaries and benefits; pride.

\section{Results}

ECL items from Valenzuela are 80, which integrate 10 dimensions (see Table 4), the reliability results of $\alpha=.962$ (see Table 2) show that the consistency of the indicators is adequate (Cronbach, 1970).

Table 2. Initial Alfa of Cronbach

\begin{tabular}{ll}
\hline Alpha of Cronbach & No. of elements \\
\hline 962 & 80 \\
\hline
\end{tabular}

The proposal to adapt the instrument is not caused by the unreliability of the instrument, but because of the need to develop more practical instruments depending on the time of the application of these, in view of the fact that the questionnaire respondents are increasingly less willing to devote their time to answer long questionnaires.

The proposal of this research is to develop from the ECL Valenzuela a much slimmer instrument. As a first analysis it was sought to define the existence of correlation between the variables and a close to $1 \mathrm{KMO}$ (Kaiser-Meyer-Oklin) was obtained (see Table 3), the test indicates that it is appropriate to conduct a factor analysis (Keiser, 1970).

Table 3. KMO and Bartlett test

\begin{tabular}{lll}
\hline \multicolumn{2}{l}{ Sample adequacy measurement from Kaiser-Meyer-Olkin } & .947 \\
\hline \multirow{2}{*}{ Bartlett's sphericity test } & Approximate Chi-squared & 27871.095 \\
& gl. & 3160 \\
& sig. & .000 \\
\hline
\end{tabular}

Bartlett's sphericity test was implemented, it revealed a significance level of .000 , this result eliminates the possibility of non-correlation lineal between variables (see Table 3), after verifying the feasibility of conducting a factor analysis, it was determined to reduce the dimensions with a maximum of iterations for convergence to 25 , implementing the Varimax method, generating a rotated solution and to ensure the rigidity of the relation between the items with the dimensions, those who presented a level above 0.6 in the matrix of rotated components, were the only ones included. 
Table 4. Dimensions of the ECL valenzuela instrument

\begin{tabular}{lll}
\hline Dimension & Items & Alpha by dimension \\
\hline Personal work & $1,2,3,4,5,6,7,8$ & .727 \\
Supervision & $9,10,11,12,13,14,15,16$ & .913 \\
Teamwork and relationships with co-workers. & $17,18,19,20,21,22,23,24$ & .910 \\
Administration & $25,26,27,28,29,30,31,32$ & .857 \\
Communication & $33,34,35,36,37,38,39,40$ & .904 \\
physical and work environment & $41,42,43,44,45,46,47,48$ & .790 \\
Training and development & $49,50,51,52,53,54,55,56$ & .866 \\
Promotion and career & $57,58,59,60,61,62,63,64$ & .890 \\
Salaries and benefits & $65,66,67,68,69,70,71,72$ & .890 \\
Pride & $73,74,75,76,77,78,79,80$ & .881 \\
\hline
\end{tabular}

Deleted items and their level of commonality are presented in Table 5, the results were obtained from the coincidence rotation in 13 repetitions.

Table 5. Eliminated items from the ECL valenzuela instrument

Communities

Extraction

1. The objectives of the work I have to do are well defined.

2. My job is interesting.

3. I feel calm and good with the responsibilities I am in charge of.

4. I have as much independence (liberty) to do my work as I wish.

5. I think that the work I am doing is very transcendent.

6. I feel very capable of performing the functions I am in charge of.

7. I think that many external factors help my work to be efficient.

8. In general, I feel that I am very productive for the institution.

15. My boss does things which are focused on the position I have.

23. I have many friends, among my various co-workers, which go beyond work environment.

25. There exist a strategic and tactical planning in the institution, and that planning is shared with the employees.

28. The norms to continue within the institution are, in quantity, the appropriate ones to help function properly within the area.

30. The personal evaluation criteria are clearly specified.

31. The way to evaluate the employee's performance is precise, continuous and fair.

32. In general, the Administration system favors the institution's functioning and the wellbeing of the employee's

33. The communication employed in the everyday labor, within my area, is clear and precise.

34. The official communication from the directors to the employees is clear and precise.

37. The orders and information which are given to the employees, are congruent and do not have contradictions.

38. The director encourage the subordinates to express their ideas in an honest and frank way.

39. In the informal communication, people try to be discrete and respectful in the institution.

40. In general, the communication in the institution is efficient, which creates an increase in productivity.

41. The physical space in which I work is always clean.

45. There does not exist discriminatory behavior from the people.

46. I have never heard complaints related to power abuse from any directors.

47. I have never heard complaints about sexual abuse.

48. In general, the physical environment and cultural values that predominate in the institution promote a favorable working climate.

49. Training offered by the institution, is congruent with its mission and objectives.

50. The institution always takes in account my interests and needs for training.

53. As part of my work, I attend the training courses I require.

54. The institution in concerned about offering, beside training course, other courses oriented to the integral development of the people.

55. The institution does designate sufficient resources to train its personal.

56. In general, the training offered by the institution has an excellent quality and promotes the best performance from our work.

57. The policies on how to do a career and achieve a promotion in the institution, are clear and precise.

64. In general, I think that the system in the institution promotes the employees to finish a career.

76. I feel very proud of working in an institution that practically hasn't any intern conflicts.

77. My family feel good about me working in that institution.

78. I feel strongly identified with the values of the institution.

The results of the new instrument which will be named Preschool CL generated from the exploratory factor analysis (AFE, for its acronyms in Spanish) is appropriate according to Reise, Waller and Comrey (2000) it was sought to find the level of practical significance, in which the items presented a minimum load factor .600, were taken into account, it includes 43 items that allow the analysis of the working climate of preschool organizations 


\section{in 9 dimensions (see table 6)}

Table 6. Internal consequence scale table, dimensions of preschool CL

\begin{tabular}{|c|c|c|}
\hline Dimension & Descripción & Items \\
\hline $\begin{array}{l}\text { Collaborative } \\
\text { Environment }\end{array}$ & $\begin{array}{l}\text { Perception of the } \\
\text { group capacity of } \\
\text { working } \\
\text { collaboratively. }\end{array}$ & $\begin{array}{l}17 \text { If there is communication among the various areas o departments of the institution, } \\
\text { which favors competitive work. } \\
18 \text { There is a culture of mutual assistance and service among the employees of the } \\
\text { institution. } \\
19 \text { We do have common goals which we try to strive en a coordinate manner. } \\
20 \text { We know how to work in teams y we apply strategies to achieve goals together. } \\
21 \text {. There is a spirit of group work or community that makes us want to work in teams } \\
\text { inside the institution. } \\
22 \text { there is a spirit of cordiality and respect among the coworkers of the institution. } \\
24 \text { In general, the relation with the other coworkers are excellent and teamwork is } \\
\text { encouraging to strive the institutional achievements. } \\
29 \text { There exist responsibility, quality and desire of continuous improvement in the } \\
\text { performance of the employees. }\end{array}$ \\
\hline $\begin{array}{l}\text { Relationship with } \\
\text { the boss }\end{array}$ & $\begin{array}{l}\text { Perception of } \\
\text { harmony of } \\
\text { interpersonal } \\
\text { relationship with the } \\
\text { boss and feedback } \\
\text { means. }\end{array}$ & $\begin{array}{l}9 \text { My boss does have confidence in me to delegate responsibilities } \\
10 \text { My boss does know how to guide me on the work I have to develop } \\
11 \text { My boss does value my work. } \\
12 \text { My boss knows how to criticize in a positive way, my work or my person } \\
13 \text { My boss always compliments me when I do my job well } \\
14 \text { My boss treats me with absolute respect } \\
16 \text { In general, I think that my boss is very capable and has the willpower to perform his } \\
\text { corresponding functions satisfactorily. }\end{array}$ \\
\hline $\begin{array}{l}\text { Professional } \\
\text { development }\end{array}$ & $\begin{array}{l}\text { Perceptions about } \\
\text { the possibility of } \\
\text { growth and } \\
\text { development in the } \\
\text { organization }\end{array}$ & $\begin{array}{l}58 \text { By the size of the institution there are many opportunities to be promoted } \\
59 \text { The likelihood of being promoted in the institution is high (if one is good } \\
\text { employee) and that decisions taken in this respect, are fair and equitable. } \\
60 \text { There is adequate preparation for an employee to ascend in the institution } \\
61 \text { In the time I've spent in the institution, I have made significant promotions. } \\
62 \text { I think I'm being taken into account in the present, to be promoted } \\
63 \text { I see a bright future in this institution. }\end{array}$ \\
\hline Remuneration & $\begin{array}{l}\text { Wellness perception } \\
\text { regarding salary and } \\
\text { benefits received }\end{array}$ & $\begin{array}{l}65 \text { My salary is more than enough to meet my needs and my family } \\
66 \text { My salary is higher than that paid by other institutions of the entity to persons } \\
\text { occupying similar positions } \\
67 \text { My salary is equal to that of my colleagues in similar jobs, received. } \\
68 \text { The institution offers benefits that far exceed those required by law. } \\
69 \text { Wage increases are typically higher than inflation in the country } \\
70 \text { There are attractive economic incentives when one does an outstanding job. } \\
71 \text { The benefits that the institution offers me, are highly significant (utility) for me. } \\
72 \text { In general, we have an efficient salary system and benefits which motivates } \\
\text { employees to improve their productivity in the institution }\end{array}$ \\
\hline $\begin{array}{l}\text { Sense } \\
\text { belonging }\end{array}$ & $\begin{array}{l}\text { Perception of pride } \\
\text { and well-being part } \\
\text { of the organization. }\end{array}$ & $\begin{array}{l}73 \text { I am proud to say that I work in this institution by the positive image it has in } \\
\text { society. } \\
74 \text { I like to work in an institution that, in my opinion, society offers excellent quality } \\
\text { educational services. } \\
75 \text { I think the mission that the institution has is very important for society } \\
79 \text { I am highly committed to the task of achieving the objectives of the institution } \\
80 \text { In general, I feel very proud to work at this institution. }\end{array}$ \\
\hline Information & $\begin{array}{l}\text { Perception of the } \\
\text { quality regarding the } \\
\text { information. }\end{array}$ & $\begin{array}{l}35 \text { The information I request arrives to me in a timely manner. } \\
36 \text { The information requested, has the virtue of being appropriate, in quantity and } \\
\text { quality, to meet my needs. }\end{array}$ \\
\hline Training & $\begin{array}{l}\text { Perception of quality } \\
\text { in training }\end{array}$ & $\begin{array}{l}51 \text { There are a lot of training courses offered to the employees. } \\
52 \text { The training offered to the staff (or employees) is at the forefront. }\end{array}$ \\
\hline Organization & $\begin{array}{l}\text { Perceived clarity of } \\
\text { functions } \quad \text { and } \\
\text { procedures }\end{array}$ & $\begin{array}{l}26 \text { Are the holder's profile and the functions of each position clearly specified? } \\
27 \text { The procedures to be followed are clearly specified. }\end{array}$ \\
\hline $\begin{array}{l}\text { Working means or } \\
\text { material }\end{array}$ & $\begin{array}{l}\text { Perceived } \\
\text { availability of } \\
\text { working material } \\
\text { that allow their } \\
\text { activities to be } \\
\text { carried out in a } \\
\text { complete and safe } \\
\text { manner. }\end{array}$ & $\begin{array}{l}42 \text { The material I have (equipment, teaching materials) to do my work are up dated and } \\
\text { in good conditions. } \\
43 \text { There are security conditions (against fire, earthquakes and other accidents) in the } \\
\text { institution. } \\
44 \text { I have the protection necessary to develop my work in a safe and healthy manner. }\end{array}$ \\
\hline
\end{tabular}

Performing this AFE, the results obtained were that in 8 components $65.8 \%$ can be produced of the original variability of variance, with a KMO $=.912>.600$ (Keiser, 1970), this means a high value, where Barlett 's sphericity test indicates a value of significance of .000 therefore it accomplishes $p<.01$ and $c^{2} 13911.705$ showing a level of significant correlation between variables, the reduced instrument of Preschool CL obtained 
a level of $\alpha=.929$ (see table 7 and 8).

Table 6. Preschool CLKMO and Bartlett's test

\begin{tabular}{|c|c|}
\hline & ,912 \\
\hline $\begin{array}{l}\text { Sample adequacy of measurement Kaiser-Meyer-Olkin. } \\
\text { Bartlett's Sphericity test }\end{array}$ & 13911,705 \\
\hline Aproxímate Chi-squared & \\
\hline $\mathrm{gl}$ & 861 \\
\hline Sig. &, 000 \\
\hline
\end{tabular}

Table 7. Final reliability

\begin{tabular}{ll}
\hline Cronbach Alpha & Number of elements \\
\hline, 929 & 43 \\
\hline
\end{tabular}

To set the level of internal consistency of the variables which are measuring a same dimension, the indicators of individual reliability Cronbach Alpha and the composed reliability as well as the analysis of extracted variance mean (AVE) are set (see Table 9).

Table 9. Analysis of reliability: Cronbach's alpha, composed reliability and analysis of the average variance extracted.

\begin{tabular}{llll}
\hline Dimensions & $\begin{array}{l}\text { Average } \\
\text { (AVE) }\end{array}$ & $\begin{array}{l}\text { variance extracted } \\
\text { (Rho) }\end{array}$ & $\begin{array}{l}\text { Composed } \\
\text { Collaborative Environment }\end{array}$ \\
Relationship with Boss & .680 & .944 & .922 \\
Professional Development & .708 & .944 & .925 \\
Remuneration & .643 & .915 & .877 \\
Sense of Belonging & .595 & .910 & .890 \\
Information & .632 & .896 & .830 \\
Training & .636 & .778 & .848 \\
Organization & .741 & .851 & .841 \\
Working mean sor materials & .703 & .826 & .795 \\
\hline
\end{tabular}

\section{Discussion}

The dimensions show an average variance extracted (AVE) of over .590 in all cases, therefore it meets the minimum .5 parameter required by the literature (Bagozzi and Yi, 1988). The internal consistency according to Cronbach's alpha of all dimensions is greater than $\alpha>0.790$, so the range of .7 reliability is accepted (Cronbach, 1970), regarding the composite reliability (THC) it is also accepted as an appropriate value above .7 (Cepeda and Roldan, 2004) and in this case all the dimensions accomplish this criteria.

\section{Conclusion}

The study of organizational climate is vital in educational organizations to establish strategies for improvement that will enable the employee to develop a professionally healthy environment, which is why it is necessary to improve the instruments designed for this type of studies as well as adapting them to fit the context, in this case the Preschool CL instrument.

This investigation showed a major finding the adjustment of 10 original dimensions ECL Valenzuela to 9 Preschool CL, removing 37 items.

According to the hypothesis, it is proved that it is possible to measure the organizational climate of preschooler of the zone Laja bajío with the Preschool CL instrument.

A confirmatory factorial analysis for Preschool CL instrument is recommended.

Based on these results, it is said that inside the organizations, actions and instruments can be established in order to improvement processes efficiently as in this case.

According to the results, the Preschool CL instrument can assess the organizational climate of Preschoolers 
based on its dimensions: Collaborative Environment, Relationship with the boss, Professional Development, Remuneration, Sense of belonging, Information, Training, Organization and Working means or materials.

The implementation of this new instrument Preschool $\mathbf{C L}$ is proposed in more preschool institutions of other federal entities to compare results.

\section{References}

Bagozzi, R. Y., \& Yi, Y. (1988). The evaluation of structural equation models. Journal of the Academy of Marketing Science, 16, 74-94. http://doi.org/10.1007/BF02723327

Bernhardt, K., Donthu, N., \& Kennett, P. (2000). A longitudinal analysis of satisfaction and profiatability. Journal of Business Research, 47, 161-171.

Boyce, A. (2010). Organizational climate and performance: An examination of causal priority [Versión Electrónica] UMI Disertation Publishing, ProQuest (3417693). Retrieved from http://0-proquest.umi.com.millenium.itesm.mx/pqdweb?did=2115527741\&sid=2\&Fmt=2\&clientId=23693 $\& \mathrm{RQT}=309 \& \mathrm{VName}=\mathrm{PQD}$

Brito, Y., \& Jiménez, J. (2009). Evaluación del clima organizacional universitario. Caso: Facultad de Ingeniería Universidad de Carabobo. Ingeniería Industrial, Actualidad Y Nuevas Tendencias, 2(1), 77-90. Retrieved from http://www.redalyc.org/pdf/2150/215016874006.pdf

Bustamente, U. M., Hernández, C. J., \& Yañez, Ag. L. (2009). Análisis del clima organizacional en el hospital regional de Talca. Revista Estudios Seriados en Gestión de Salud, 5(11), 20-39.

Bustos, P., Miranda, M. y Peralta, R. (2004). Clima organizacional. Retrieved from http://www.gestiopolis.com/recursos/documentos

Caracheo, F. (2001). Modelo educativo (propuesta de diseño), Dirección General de Institutos Tecnológicos, Coordinación Sectorial de Normatividad Académica. México: CIDET.

Cepeda, G., \& Roldán, J. L. (2004). Aplicando en la Práctica la Técnica PLS en la Administración de Empresas. Congreso de la ACEDE, 19(20-21). Retrieved from http://www.scielo.br/scielo.php?script=sci_nlinks\&ref=000167\&pid=S1807-1775200900010000300009\&ln $\mathrm{g}=\mathrm{en}$

Chiang V. M. (2004). Relación entre el clima organizacional y satisfacción laboral en grupos de profesores y/o investigadores universitarios. Tesis doctoral, Universidad Ponticificia Comillas de Madrid,

Cronbach, L. (1970). Essentials of Psychological testing (3rd ed.). New York, N.Y.: Harper y Row.

Díaz, R., \& Zavala, G. (2006). Diagnóstico de clima organizacional: un análisis conceptual y metodológico, Instituto de Comunicación e Imagen, Universidad de Chile.

Dorman, J. (1999). The development and validation of an instrument to assess institutional - level environment in Universities. Learning Enviroments Research, 1(3), 333-352. http://doi.org/10.1023/A:1009965621296

Fitzgerald, L. Fritz, D., Hulin, C., Gelfand, M., \& Magley, V. (1997). Antecedents and consequence of sexual harassment in organizations: A test of an integrated mode. Journal of Applied Psychology, 82(3), 578-589. Retrieved from http://www.gelfand.umd.edu/fitzgeraldetal1997.pdf

Fuentes, F. (2004). Auditoria del clima laboral, la influencía de factores externos. Trabajo y Seguridad Social, Recursos Humanos, 254, 123-158. https://dialnet.unirioja.es/servlet/articulo?codigo=859606

García, I. (2006). La formación del clima psicológico y su relación con los estilos de liderazgos. Tesis doctoral, Universidad de Granada.

García, Y., \& Mendoza, J. (2015). Influencias de los estilos de liderazgo en el clima de una institución educativa de nivel medio superior. Administración Para el Desarrollo, 8, 21-50.

Garza, D. (2010). El clima organizacional en la dirección general de ejecución de sanciones de la secretaría de seguridad pública en Tamaulipas. Tesis para obtener el grado de Maestro en Dirección Empresarial con énfasis en recursos humanos. Universidad Autónoma de Tamaulipas. Retrieved from https://fcav.uat.edu.mx/siap/data/TMDE021.pdf

Goncalvez, A. (2001). Fundamentos del clima organizacional. Trillas, México.

Goñi, L. (2011). Clima organizacional en los servicios de cuna - jardín de la ciudad de Lima. XII Congreso Internacional de Teoría de la Educación. 
Gunter, B., \& Furnham, A. (1996). Biographical and climate predictors of job satisfaction and pride in Organization. The Journal of Psychology, 130, 193-208. Retrieved from http://www.tandfonline.com/doi/abs/10.1080/00223980.1996.9915001

Gúzman, P., Bójorquez, G., \& Serrano, M. (2009). Diagnóstico del clima organizacional, estrategia para medir el marketing interno de una institución educativa particular del nivel básico de Cd Obregón, Congreso Internacional de Negocios, Instituto Tecnológico de Sonora, 21-23 de octubre. Retrieved from http://www.itson.mx/publicaciones/pacioli/Documents/no65/96.pdf

Hernández, M. Y. (2009). Clima organizacional y compromiso con la organización. Referido por los profesores investigadores de tiempo completo (PITC) de la Universidad Autónoma de San Luis Potosí. Tesis de doctorado. Universidad Autonoma de San Luis Potosi. México.

Hernández, S. R. (2008). Exploración del modelo de los valores en competencia en el medio laboral mexicano y su vinculación con el clima organizacional. Tesis doctoral, Universidad de Celaya.

Hidalgo, G., Xicotencatl, M., \& Rodríguez, J. (2008). Diagnóstico de clima organizacional en la división académica de Educación y Artes. Semana de divulgación y video científico. Universidad Autónoma Juárez de Tabasco. Retrieved from http://www.archivos.ujat.mx/dip/divulgacion\%20y\%20video\%20cinetifico\%202008/DAEA/GHidalgoQ.pd $\mathrm{f}$

Hinojosa, C. (2010). Clima organizacional y satisfacción laboral en profesores del Colegio Sagrados Corazones Padres Franceses. Trabajo de evaluación final, Programa de doctorado en gestión y políticas educativas, Universidad de Playa Ancha.

Ibarra, E. (1998). La Universidad Autónoma Metropolitana y los límites de la modernización. Análisis de las significaciones de una experiencia institucional aparentemente exitosa (1974-1992). In Ibarra, E. (Ed.), La universidad ante el espejo de la excelencia (pp. 243-348). En juegos organizacionales, México, Universidad Autónoma Metropolitana-Iztapalapa.

Joyce, W., \& Slocum, J. (1982). Climate discrepancy: Redefing the concept of psychological and organizational climate. Human Relations, 35(11), 951-971. http://doi.org/10.1177/001872678203501102

Keiser, H. F. (1970). A second generation Little jiffy. Psychometrika, 35, 401-415.

Lewin, K. (1936). Principles of topological psychology. Mc Graw Hill, USA.

Lewin, K., Lippitt, R., \& White, R. (1939). Pattems of aggressive behavoir in experimental created "social climate. Journal of Social Psychology, 10, 271-299.

Litwin, G., \& Stringer, R. (1968). Motivation and organizational climate. Harvard University Graduate School of Business Administration, Boston: Press.

Martínez, M., \& Rodríguez, O. (2011). Caracterización del clima organizacional en instituciones de educación infantil, privadas y públicas, herramienta importante en el desarrollo del sector educativo. Tesis de Licenciatura. Universidad de la Sabana.

Mayer, J., Allen, N., \& Smith, C. (1993). Commitment to organizations and occupations: Extension and test of a three - component conceptualization. Journal of Applied Psychology, 78(4), 538-551.

Mayer, J., Allen, N., \& Smith, C. (1993). Commitment to organizations and occupations: Extension and test of a three - component conceptualization. Journal of Applied Psychology, 78(4), 538-551.

McKnigth, D., \& Webster, J. (2001). Collaborative insight of privacy invasion? Trust climate as a lens for understanding acceptance of awareness systems. In Cooper, C., Cartwright, S. y Earley, P. (Eds), International handbook of organizational culture and climate. NY, John Wiley.

Mejía, A., Reyes, O., \& Arzola, M. (2006). Medición del clima organizacional en instituciones de educación superior. Revista Universidad, Ciencia y Tecnología. 10(38), 55-61. http://www.scielo.org.ve/pdf/uct/v10n38/art02.pdf

Michela, J., \& Burke, W. (2000). Organizational culture and climate in transformations for quality and innovation. In Ashkanasy, M., Wilderom, C., \& Peterson, M. (Eds.), Handbook of organizational culture and climate (pp. 117-129). Sage Publications, Inc. London.

Montaño, L. (2001). Dilemas y desafios de la investigación en administración en México. Revista de Contaduría y Administración, 202, 21-28. Retrieved from http://www.redalyc.org/pdf/395/39520203.pdf 
Muñoz, C. (1998). Como elaborar y asesorar una investigación de tesis. Prentice - Hall Hispanoamericana, S.A. México.

Murphy, J. (1966). An investigation into certain personality factors of elementary school teachers and principals whit reference to organizational climate of the school.Athens, GA: University of Georgia.

O'Driscoll, M., \& Evans, R. (1988). Organizational factors and perceptions of climate in three psychiatric units. Human Relations, 41, 371-388. Retrieved from http://hum.sagepub.com/content/41/5/371.abstract

Ojeda, J. (2013). Análisis del clima psicológico y su relación con los estilos de pensamiento bajo la perspectiva de la teoría HBDI. Tesis doctoral, Universidad de Celaya, México.

Ojeda, J. (2014). Clima organizacional en instituciones de educación primaria. Centro de Investigación de Ciencias Administrativas y Gerenciales, 11(2), 3-26. Retrieved from http://publicaciones.urbe.edu/index.php/cicag/article/viewArticle/2575/4062

Paredes, B., Sánchez, M., \& De la Cruz, F. (2012). La relación entre el clima organizacional y el desempeño docente dentro del aula, en el nivel preescolar. XVI Congreso ACACIA: Retos de las ciencias administrativas desde las economías emergentes, evolución de sociedades. 22 - 25 de mayo, Instituto Tecnológico y de Estudios Superiores de Monterrey, Campus Ciudad de México. Retrieved from http://acacia.org.mx/busqueda/pdf/02_PF638_Clima_Laboral.pdf

Patterson, M., Warr, P., \& West, M. (2004). Organizational climate and company performance: The role of employee affect and employee level. Journal of Occupational and Organizational Psychology, 77, 193-216. Retrieved

from http://attach3.bdwm.net/attach/0Announce/groups/GROUP_C/Managepsy/D50994C70/M.1098876514.A/1 3705862.pdf

Peiró, J. M., González, V., \& Ramos, J. (1991). Psychological climate and employee's work experiences. In Gyorgy Hunyady (Ed.), European research project on organizational cultures. Simposium realizado en el $2^{\circ}$ European Congress of Psychology, Budapest, Hungary

Prisco, X., \& Salaiza, F. (2012). Relación entre el clima laboral y la motivación del personal en una secundaria pública. Memorias del XVII Congreso Internacional de Contaduría, Administración e Información. $3-5$ de octubre, Ciudad de México. Retrieved from http://congreso.investiga.fca.unam.mx/docs/xvii/docs/E13.pdf

Reise, S. P., Waller, N. G., \& Comrey, A. L. (2000). Factor Analysis and scale revisión. Psychological Assesment, 12(3), 287-297. Retrieved from http://psych.colorado.edu/ willcutt/pdfs/Reise_2000.pdf

Reyes, O. (2007). Evaluación cuantitativa del clima organizacional en la educación superior. IX Congreso Nacional de Investigación Educativa, Merida, Yucatan, 5 - 9 noviembre. Retrieved from http://www.comie.org.mx/congreso/memoriaelectronica/v09/ponencias/at13/PRE1178701756.pdf

Rodríguez, A. (1996). Hacia una nueva cultura en las organizaciones. In Rodríguez, A. (Ed.), Los recursos humanos en las administraciones públicas (pp. 469-497). Madrid: Tecnos.

Rouiller, J., \& Goldstein, I. (1993). The relationship between organizational transfer climate and positive transfer of training. Human Resource Development Quarterly, 4(4), 377-390. http://doi.org/10.1002/hrdq.3920040408

Salaiza, F. (2008). Medición del clima organizacional en instituciones educativas. Memorias del XII Congreso Anual de la Academia de Ciencias de la Administración, A.C. 14 - 16 de mayo, Tijuana, Baja California. Retrieved from http://acacia.org.mx/busqueda/pdf/M02P53.pdf

Salaiza, L., \& Vela, N. (2007). Validación de un instrumento para medir el clima laboral en instituciones educativas. II Congreso Internacional de Innovación Educativa: Innovación, valor agregado al conocimiento. Noviembre, Ciudad de México. Retrieved from https://repositorio.itesm.mx/ortec/handle/11285/568155

Salminen, S., \& Seppälä, A. (2005). Safety climate in finnish- and Swedish -speaking companies, International Journal of Occupational Safety and Ergonomics, 11(4), 389-397.

Schneider, B. (1975). Organizational climate: An essay. Personnel Psychology, 28, 447-479. Retrieved from http://onlinelibrary.wiley.com/doi/10.1111/j.1744-6570.1975.tb01386.x/abstract

Schneider, B., Bowen, D., Eherhart, M., \& Holcombe, K. (2000). The climate service: evolution of a construct. In Ashkanasy, N., Wilderom, C. y Peterson, M. (Eds.), Handbook of organizational culture and climate (pp. 21-36). Sage Publications, Thounsand Oaks, CA, USA. 
Silva, M. (1992). Hacia una definición comprehensive del clima organizacional. Revista de psicología general y aplicada, 45(4), 443-451.

Sotelo, J., Arrieta, D., \& Figueroa, E. (2015). Medición del clima organizacional gubernamental utilizando calidad en el servicio como parámetro. Revista Global de Negocios, 3(4), 27-38.

Stringer, R. (2002). Leadership and organizational climate. Prentice Hall, New Jersey, USA.

Tolman, E. C. (1932). Conducta propositiva en animales y en el hombre. Appleton - Century, New York.

Toro, F., \& Cabrera, H. (2002). Análisis del compromiso organizacional en empresas colombianas, Revista interamericana De Psicología Ocupacional, 21, 14-17. Retrieved from http://revista.cincel.com.co/cincel/index.php/RPO/article/view/39

Valenzuela, R. (2003). ECL. Encuesta de Clima Organizacional. Instituto Tecnológico y de Estudios Superiores de Monterrey. Campus Estado de México.

Valenzuela, R. (2005). Evaluación de Instituciones Educativas. Editorial Trillas. Ciudad de México.

Velázquez, R. (2004). Clima organizacional a nivel universitario. Editorial Prentice Hall, México.

Zuloaga, M. (2001). Clima Organizacional, República de Colombia, Departamento Administrativo de la Función Pública.

\section{Copyrights}

Copyright for this article is retained by the author(s), with first publication rights granted to the journal.

This is an open-access article distributed under the terms and conditions of the Creative Commons Attribution license (http://creativecommons.org/licenses/by/4.0/). 